\title{
ANALISIS KETERSEDIAAN RUANG TERBUKA HIJAU DAN TINGKAT PERKEMBANGAN WILAYAH DI KOTA CIMAHI, PROVINSI JAWA BARAT
}

\section{The Analysis of Greenery Open Space Availability and Level of Development in Cimahi City, West Java Province}

\author{
Santun Risma Pandapotan Sitorus ${ }^{1)^{*}}$, Mutiara Ashri2) dan Dyah Retno Panuju1) \\ 1) Departemen Ilmu Tanah dan Sumberdaya Lahan, Fakultas Pertanian IPB, Jl. Meranti Kampus IPB Darmaga \\ Bogor 16680 \\ 2) Alumni Departemen Ilmu Tanah dan Sumberdaya Lahan, Fakultas Pertanian IPB, J1. Meranti Kampus IPB \\ Darmaga Bogor 16680
}

\begin{abstract}
Environmental quality of cities and regencies degrade continuously and worsened by declining of greenery open space acreage. It is due to population growth and increasing demand of land for settlements and facilities development. The status of Cimahi turned into a municipality since 2001. Form the beginning, Cimahi has developed intensively, nonetheless balance condition of environment, social and economic should be maintained carefully. One of the environmental aspects is greenery open space composition. This research aims to describe land use change process, to identify the availability of greenery open space, to understand the dynamics of developmental process Cimahi city, and to determine factors affecting the availability of greenery open space in Cimahi city. The result shows that during the years of 2007-2011 land use of Cimahi city changed as much as 420.6 hectares turned into settlements. The availability of greenery open space in Cimahi in 2011 was 738 hectares or $17.9 \%$ of the total area. It was not sufficient for the total population of Cimahi city according to regulation of The Ministry of Public Works (PERMEN PU) No. 05/PRT/M/2008. Development of Cimahi city in sub district showed unequally where, several regions consistenly stayed at the same level of hierarchy by the time, while others were fluctuated. Factors affecting the availability of greenery open space in Cimahi city were allocation for building areas in the regional spatial plan $(R T R W)$, and population density. Other factors, such as variation of facilities, population growth, and previous built up areas (2011) were not affecting significantly.
\end{abstract}

Keywords: Area development level, Cimahi city, Greenery open space

\section{ABSTRAK}

Kualitas lingkungan kota dan kabupaten terus menurun yang ditunjukkan salah satunya oleh menurunnya luas ruang terbuka hijau (RTH). Hal ini disebabkan antara lain oleh adanya pertambahan penduduk dan kebutuhan ruang untuk pembangunan permukiman dan fasilitas pelayanan. Cimahi merupakan wilayah yang baru ditetapkan sebagai kota pada tahun 2001. Sejak awal pembentukannya, Kota Cimahi telah menunjukkan perkembangan dan kemajuan yang cukup pesat sehingga perlu diikuti oleh upaya-upaya menjaga keseimbangan antara lingkungan sosial dengan ekonomi. Salah satunya adalah komposisi ruang terbuka hijau. Tujuan penelitian ini adalah untuk mengetahui perubahan penggunaan lahan di Kota Cimahi, mengetahui ketersediaan ruang terbuka hijau di Kota Cimahi, mengetahui dinamika tingkat perkembangan wilayah di Kota Cimahi dan mengetahui faktor-faktor yang mempengaruhi ketersediaan ruang terbuka hijau di Kota Cimahi. Pada tahun 20072011 menunjukkan terjadi perubahan penggunaan lahan yang dicirikan oleh perubahan penggunaan lahan lain menjadi pemukiman sebesar 420.6 ha. Adapun ketersediaan ruang terbuka hijau Kota Cimahi pada tahun 2011 hanya sebesar 738 ha atau $17.9 \%$ dari total seluruh wilayah sehingga belum bisa mencukupi kebutuhan seluruh penduduk di Kota Cimahi. Dinamika tingkat perkembangan wilayah di Kota Cimahi menunjukkan ada kelurahan-kelurahan yang konsisten di hirarkinya dan ada yang bersifat fluktuatif. Faktor-faktor yang mempengaruhi ketersediaan ruang terbuka hijau di Kota Cimahi adalah alokasi lahan terbangun dalam RTRW, kepadatan penduduk, jumlah jenis fasilitas, pertumbuhan penduduk dan lahan terbangun tahun 2011.

Kata kunci : Tingkat perkembangan wilayah, Kota Cimahi, ruang terbuka hijau

\section{PENDAHULUAN}

Perkembangan perkotaan berpengaruh negatif pada berbagai aspek, termasuk aspek lingkungan. Dalam tahap awal perkembangan kota, sebagian besar lahan merupakan ruang terbuka hijau $(\mathrm{RTH})$, namun karena pertambahan penduduk dan kebutuhan ruang untuk memenuhi pembangunan, seperti fasilitas-fasilitas untuk menunjang perkembangan aktivitas masyarakat, maka RTH cenderung terkonversi menjadi kawasan terbangun. 
Hal ini diperburuk dengan lemahnya penegakan hukum dan kurang sadarnya masyarakat terhadap aspek penataan ruang kota. Akibatnya, muncul permukiman kumuh di beberapa ruang kota dan kemacetan lalu lintas di ruas-ruas jalan tertentu (Dwiyanto, 2009). Sebagai ilustrasi, menurut Sitorus et al. (2011) luas RTH di Jakarta Selatan pada tahun 2002 sampai tahun 2007 mengalami penurunan sebesar 362.21 ha. Hal ini disebabkan adanya alih fungsi lahan RTH menjadi penggunaan lain serta adanya peningkatan jumlah penduduk yang disertai dengan peningkatan sarana prasarana seperti fasilitas pendidikan, fasilitas kesehatan, dan fasilitas perekonomian.

Berdasarkan pemakaiannya, ruang terbuka dapat dibagi menjadi tiga, yaitu ruang terbuka privat, komunal, dan publik. Ruang terbuka privat digunakan hanya oleh pemilik bangunan, seperti halaman rumah, balkon, dan teras. Ruang terbuka komunal merupakan ruang terbuka yang diperuntukkan bagi sekelompok orang, umumnya penghuni suatu lingkungan perumahan dan biasanya digunakan untuk kegiatan sosial penghuni. Contoh dari ruang terbuka komunal adalah taman lingkungan, ruang terbuka yang terletak di antara beberapa rumah (taman bermain dan ruang untuk olahraga). Ruang terbuka publik merupakan ruang terbuka yang bisa digunakan oleh siapa saja, seperti taman kota, plaza, tempat parkir, dan sebagainya (Rahmi, 2002).

Menurut Samsudi (2010), fungsi RTH dapat dibedakan menjadi 2, yaitu: (a) Fungsi utama (intrinsik) atau fungsi ekologis dan (b) Fungsi tambahan (ekstrinsik) atau fungsi arsitektural, sosial, dan ekonomi. RTH berfungsi secara ekologis, artinya dengan adanya RTH diharapkan dapat memberi kontribusi dalam peningkatan jumlah dan kualitas air tanah, mencegah terjadinya banjir, mengurangi polusi udara, dan pendukung dalam pengaturan iklim mikro. RTH untuk fungsi-fungsi lainnya (sosial, arsitektural, dan ekonomi) diharapkan bisa menciptakan ruang untuk interaksi sosial, sarana rekreasi, dan sebagai penanda kawasan, sehingga bisa meningkatkan nilai keindahan dan kenyamanan untuk kawasan tersebut keberadaan taman dan jalur hijau. Selain itu, adanya RTH diharapkan bisa meningkatkan minat masyarakat/wisatawan untuk berkunjung ke suatu kawasan sehingga dapat meningkatkan kegiatan ekonomi.

Samsudi (2010) menyatakan manfaat yang diharapkan dari perencanaan RTH di kawasan perkotaan antara lain sebagai sarana untuk mencerminkan identitas daerah, sarana penelitian, pendidikan, dan penyuluhan, sarana rekreasi serta interaksi sosial, meningkatkan nilai ekonomis lahan, sarana aktivitas sosial bagi anak-anak, remaja, dewasa, dan manula, sarana evakuasi untuk keadaan darurat, memperbaiki iklim mikro, serta meningkatkan cadangan oksigen di perkotaan.

Penelitian ini dimaksudkan untuk mempelajari kondisi RTH di salah satu kota di Jawa Barat, yaitu Kota Cimahi. Kota Cimahi merupakan wilayah yang ditetapkan sebagai Kota pada tanggal 21 Juni 2001 yang sebelumnya merupakan Kota Administratif (Kotif). Sejak awal pembentukan, Kota Cimahi telah menunjukkan perkembangan dan kemajuan yang cukup pesat yang ditandai dengan tingginya laju pertumbuhan penduduk, pertumbuhan ekonomi, dan besarnya potensi pendapatan asli daerah (PAD). Kondisi tersebut perlu diikuti dengan adanya keseimbangan antara kondisi lingkungan, sosial, dan ekonomi. Salah satunya adalah komposisi RTH di Kota Cimahi (Pemkot Cimahi, 2012).

Berdasarkan data BLH Kota Cimahi (2011) diketahui bahwa Kota Cimahi mempunyai luasan RTH sebesar 621.3 ha atau kurang lebih $15.4 \%$ dari total luas wilayah Kota Cimahi. Jika merujuk pada UU No. 26 tahun 2007 pasal 29 luasan RTH tersebut jauh dibawah luasan yang disyaratkan bagi RTH suatu kota. Dari uraian tersebut dan melihat kondisi ketersediaan RTH di Kota Cimahi, maka sangat penting untuk menetapkan langkah dan strategi penambahan RTH di Kota Cimahi guna mendukung kelangsungan aktivitas perkotaan yang lebih optimal.

Tujuan penelitian ini adalah (1) mengetahui perubahan penggunaan lahan di Kota Cimahi, (2) mengetahui ketersediaan dan kecukupan RTH di Kota Cimahi, (3) mengetahui dinamika tingkat perkembangan wilayah di Kota Cimahi, serta (4) mengetahui faktor-faktor yang mempengaruhi ketersediaan RTH di Kota Cimahi.

\section{BAHAN DAN METODE}

\section{Lokasi Penelitian}

Lokasi penelitian yang dipilih adalah Kota Cimahi (Gambar 1) di Jawa Barat. Analisis data yang dilakukan dalam penelitian ini dikerjakan di Studio Bagian Perencanaan Pengembangan Wilayah, Departemen Ilmu Tanah dan Sumberdaya Lahan, Fakultas Pertanian, Institut Pertanian Bogor.

\section{Jenis Data, Sumber Data dan Alat Penunjang}

Data yang digunakan adalah data primer dan data sekunder. Data primer terdiri dari citra Quickbird tahun 2011 yang diunduh dari website earth.google.com dan data survei lapang. Data sekunder terdiri dari data PDRB, data potensi desa tahun 2003, 2006, 2008, dan 2011 yang meliputi data jumlah dan jenis fasilitas, aksesibilitas, dan data jumlah penduduk, peta administrasi Kota Cimahi, peta penggunaan lahan Kota Cimahi, peta RTRW Kota Cimahi tahun 2011-2031, serta beberapa peta penunjang lainnya yang diperoleh dari Badan Perencanaan dan Pembangunan Daerah (BAPPEDA) Kota Cimahi. Alat penunjang yang digunakan pada penelitian ini adalah seperangkat komputer dengan perangkat lunak ArcGIS 9.3, Google Earth, Microsoft Excel, Microsoft Word, Statistica 8, Global Mapper, Kamera Digital, dan GPS.

\section{Pengumpulan Data}

Data yang dikumpulkan terdiri dari data spasial, data numerik serta data penunjang hasil survei lapangan. Data spasial terdiri dari peta administrasi, peta jalan, peta RTRW Kota Cimahi tahun 2011-2031, peta penggunaan lahan tahun 2007 yang didapatkan dari BAPPEDA dan citra Quickbird Kota Cimahi dengan resolusi spasial 0.6 m. Citra ini selanjutnya didigitasi dengan menggunakan perangkat lunak Google Earth untuk mengetahui penggunaan lahan dan luasan RTH eksisting tahun 2011. Proses interpretasi dilakukan secara visual berdasarkan kenampakan penutupan lahan, khususnya kenampakan RTH. Peta Penggunaan Lahan 2007 selanjutnya ditumpangtindihkan dengan peta penggunaan lahan tahun 2011 untuk mengetahui perubahan penggunaan lahan Kota 
Cimahi tahun 2007-2011. Dari hasil digitasi selanjutnya dapat diketahui ketersediaan RTH yang ada di Kota Cimahi tahun 2011. Data numerik terdiri dari data PDRB, dan data potensi desa tahun 2003, 2006, 2008 dan 2011. Data penunjang hasil survei lapang meliputi pengamatan penggunaan lahan berupa RTH dan penggunaan lahan lain di Kota Cimahi di 117 titik contoh. Pemilihan titik-titik contoh tersebut didasarkan pada lokasi dinamika perubahan penggunaan lahan serta keberadaan RTH yang telah ditetapkan oleh Pemkot Cimahi dengan luasan relatif besar. Proporsi penarikan contoh RTH publik didasarkan pada data RTH Publik Kota Cimahi seperti disajikan pada Tabel 1.

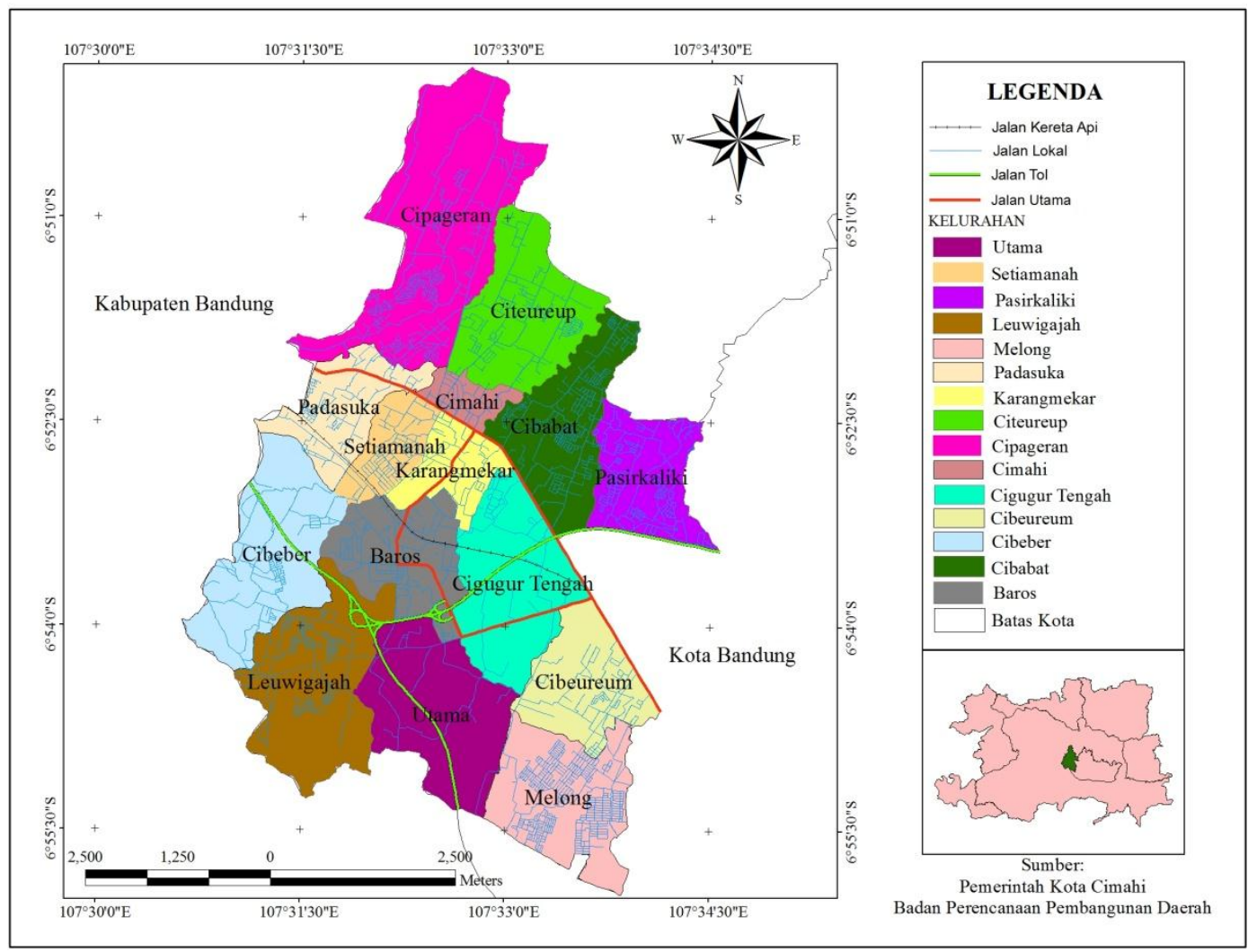

Gambar 1. Lokasi penelitian

Penentuan jumlah titik contoh pada berbagai perubahan penggunaan lahan di Kota Cimahi tahun 20072011 dihitung dari jumlah poligon hasil digitasi yaitu jumlah poligon pada jenis perubahan tertentu dibagi dengan total poligon yang berubah kemudian dikali 100 . Selanjutnya dilakukan pembulatan ke atas. Hasil yang diperoleh adalah 108 titik contoh.

Tabel 1. Proporsi penarikan contoh RTH publik Kota Cimahi tahun 2011

\begin{tabular}{lllr}
\hline Kode & Lokasi & Kelurahan & Luas $\left(\mathbf{m}^{2}\right)$ \\
\hline CR40 & Taman Pemkot dan Walikota & Cibabat & $6,500.0$ \\
CR28 & Taman Underpass Cibabat & Cibabat/Cigugur Tengah & $1,000.2$ \\
CR21 & Taman Alun-alun & Cimahi & $4,584.6$ \\
CR22 & Taman Kartini & Baros & $6,500.0$ \\
CR20 & Taman Median Jalan Akses Tol Baros & Baros & $1,200.0$ \\
CR48 & Taman Trotoar Jalan Baros & Baros & 391.1 \\
CR46 & Taman Akses Tol Baros & Baros & $11,587.0$ \\
CR17 & Taman Stasiun KA & Baros & $1,125.4$ \\
CR18 & Taman Oerip Soemoharjo (dekat Dustira) & Baros & $1,600.0$ \\
CR24 & Taman segtiga Akses Tol Baros & Baros & 15.0 \\
CR63 & Taman segitiga Nanjung & Utama & 30.0 \\
\hline
\end{tabular}




\section{Analisis Data}

Teknik analisis data yang digunakan untuk tujuan (1) adalah analisis spasial berupa koreksi geometri dan digitasi citra serta tabulasi data. Untuk tujuan (2) digunakan analisis seperti tujuan (1) dan analisis kecukupan RTH berdasarkan luas wilayah dan jumlah penduduk berdasarkan UU No. 26 Tahun 2007 dan Peraturan Menteri Pekerjaan Umum No. 5/PRT/M/2008. Untuk tujuan (3) digunakan analisis skalogram sederhana dan analisis entropi, sedangkan untuk tujuan (4) digunakan teknik pendugaan pertumbuhan dan analisis regresi berganda. Uraian singkat masing-masing teknik analisis yang digunakan adalah sebagai berikut:

\section{Analisis Perubahan Penggunaan Lahan Kota Cimahi Tahun 2007-2011}

Analisis ini meliputi proses digitasi dan koreksi geometri lain yang dilakukan dengan perangkat lunak ArcGis 9.3, ArcView 3.3 dan Google Earth terhadap petapeta yang telah disiapkan. Proses digitasi dilakukan terhadap peta administrasi, peta jalan, peta penggunaan lahan tahun 2007, peta RTRW Kota Cimahi tahun 20112031. Analisis penggunaan lahan aktual terbaru tahun 2011 menggunakan citra Quickbird yang dideliniasi secara visual dengan menggunakan perangkat lunak Google Earth. Proses interpretasi dilakukan untuk mengklasifikasikan 10 jenis penggunaan lahan yaitu pemukiman, bangunan, rumput, badan air, perkebunan, sawah, ladang, lahan terbuka, industri, dan RTH yang didasarkan pada unsur-unsur interpretasi seperti rona, bentuk, ukuran, bayangan, pola dan asosiasi. Hasil digitasi diubah ke dalam bentuk shapefile dengan menggunakan perangkat lunak Global Mapper sehingga diperoleh peta penggunaan lahan tahun 2011. Peta penggunaan lahan tahun 2007 ditumpangtindihkan dengan peta penggunaan lahan tahun 2011 untuk mendapatkan peta perubahan penggunaan lahan Kota Cimahi periode tahun 2007-2011. Hasil luasan perubahan penggunaan lahan disajikan dalam bentuk matriks perubahan penggunaan lahan.

\section{Analisis Ketersediaan RTH di Kota Cimahi}

Pada tahap ini dilakukan tabulasi data dengan membangun grafik dan tabel dari penggunaan lahan tahun 2011 berupa RTH untuk mengetahui ketersediaan RTH di Kota Cimahi pada tahun 2011. Kemudian dilakukan perhitungan kecukupan RTH berdasarkan luas wilayah dan jumlah penduduk. Luas RTH yang dibutuhkan didasarkan pada luas wilayah dihitung dengan cara mengalikan $20 \%$ dari luas wilayah masing-masing kelurahan sesuai dengan UU No. 26 Tahun 2007, sehingga didapatkan kecukupan RTH masing-masing kelurahan di Kota Cimahi. Kecukupan RTH yang didasarkan pada jumlah penduduk dihitung dengan cara mengalikan jumlah penduduk dengan standar luas RTH per kapita yang diatur dalam Permen PU No. 5 Tahun 2008 sebesar $20 \mathrm{~m}^{2}$ kapita $^{-1}$. Persamaan yang digunakan adalah sebagai berikut:

\section{Keterangan:}

$$
\text { RTH Pi }=\text { Pi } x \text { k .... } \mathrm{m}^{2} / \text { penduduk }
$$

$\mathrm{k}=$ Nilai ketentuan luas RTH per penduduk berdasarkan Permen PU No. 05/PRT/M/2008.

$\mathrm{Pi}=$ Jumlah penduduk di wilayah $\mathrm{i}$.
3. Identifikasi Areal yang Berpotensi untuk Penambahan RTH

Areal yang berpotensi untuk penambahan RTH diidentifikasi dengan menggunakan analisis spasial yaitu dilakukan dijitasi visual pada citra Quickbird tahun 2011 berdasarkan kondisi aktual penggunaan lahan berupa lahan terbuka dan rumput. Hasil dari dijitasi tersebut berupa peta areal potensial untuk penambahan RTH. Peta areal potensial untuk penambahan RTH yang telah didijitasi kemudian ditumpangtindihkan dengan peta administrasi sehingga didapatkan peta areal yang berpotensi untuk penambahan RTH pada masing-masing kelurahan.

Luas areal penambahan RTH yang telah didigitasi kemudian ditambahkan dengan luas RTH aktual tahun 2011 dan dibandingkan dengan luas kebutuhan RTH berdasarkan jumlah penduduk tahun 2011 untuk mengetahui apakah dengan penambahan luas areal RTH dapat mencukupi kebutuhan RTH berdasarkan jumlah penduduk atau tidak. Perhitungan dilakukan dengan analisis deskriptif dan disajikan dalam bentuk grafik dan tabel.

\section{Analisis Dinamika Tingkat Perkembangan Wilayah di Kota Cimahi}

Analisis tingkat perkembangan wilayah dilakukan dengan menggunakan teknik skalogram. Teknik ini digunakan untuk menentukan tingkat perkembangan wilayah serta menentukan hirarki pusat-pusat wilayah penopang yang mendukung wilayah sebagai pusat aktivitas. Hirarki ditentukan berdasarkan jumlah unit dan jumlah jenis fasilitas. Unit wilayah yang memiliki fasilitas dengan kuantitas yang lebih banyak dan jenis yang lebih kompleks memiliki tingkat hirarki yang lebih tinggi. Data yang digunakan dalam analisis skalogram sederhana ini adalah data fasilitas pendidikan, ekonomi, dan sosial. Fasilitas pendidikan meliputi variabel jumlah TK, SD, SMP, SMA/sederajat, dan perguruan tinggi. Fasilitas ekonomi meliputi variabel jumlah warnet, wartel, warung/toko, supermarket, tempat makan, penginapan, industri kerajinan, bank umum, dan koperasi. Fasilitas kesehatan meliputi variabel jumlah rumah sakit, rumah sakit bersalin, poliklinik, puskesmas, tempat praktek dokter dan bidan, posyandu dan apotek. Fasilitas sosial meliputi variabel jumlah tempat peribadatan.

Selain analisis skalogram, digunakan pula analisis entropi untuk menentukan tingkat pemerataan wilayah. Data yang digunakan adalah data PDRB Kota Cimahi tahun 2001-2009. Dalam analisis ini apabila nilai entropi semakin mendekati maksimum maka penyebaran aktifitas perekonomian di seluruh wilayah relatif merata dan ragam di setiap jenis aktifitas ekonomi relatif sama. Persamaan yang digunakan adalah sebagai berikut:

dimana:

$$
\mathbf{S}=-\sum \mathbf{P}_{\mathbf{i}} \operatorname{Ln}\left(\mathbf{P}_{\mathbf{i}}\right)
$$

$\mathrm{P}_{\mathrm{i}}=$ peluang yang dihitung dari persamaan $\mathrm{X}_{\mathrm{i}} / \sum \mathrm{X}_{\mathrm{i}}$

$\mathrm{X}_{\mathrm{i}}=$ nilai suatu aktifitas di suatu wilayah

\section{Analisis Faktor-Faktor yang Mempengaruhi Ketersediaan RTH}

Analisis ini dilakukan dengan teknik regresi berganda. Analisis regresi digunakan untuk membuat model pendugaan terhadap nilai suatu parameter dari 
parameter-parameter lain yang diamati. Analisis regresi dilakukan dengan menggunakan perangkat lunak Statistica. Metode analisis yang digunakan adalah regresi bertatar. Persamaan (model) yang digunakan adalah:

dimana:

$$
\mathbf{Y}=\mathbf{A}_{0}+\mathbf{A}_{1} \mathbf{X}_{1}+\ldots \ldots \ldots+\mathbf{A}_{\mathbf{n}} \mathbf{X}_{n}
$$

Y= Ketersediaan RTH 2011 (ha)

$\mathrm{X}=$ Variabel bebas

$\mathrm{A}=$ Koefisien Variabel

Variabel bebas (X) yang diduga berpengaruh pada ketersediaan RTH antara lain: pertumbuhan penduduk, kepadatan penduduk, jumlah seluruh fasilitas (fasilitas ekonomi, fasilitas pendidikan, fasilitas kesehatan, fasilitas sosial), jumlah jenis seluruh fasilitas, luas lahan terbangun tahun 2011, luas lahan tidak terbangun tahun 2011, alokasi lahan terbangun dalam RTRW, alokasi lahan tidak terbangun dalam RTRW, dan alokasi RTH dalam RTRW. Variabel pertumbuhan penduduk dihitung menggunaan teknik pendugaan pertumbuhan. Rumus matematik dari teknik pendugaan pertumbuhan adalah:

dimana:

$$
\text { Pertumbuhan }=\left(\mathbf{X t}_{\mathbf{1}}-\mathbf{X t}_{\mathbf{0}}\right) / \mathbf{X t}_{\mathbf{0}}
$$

$\mathrm{Xt}_{0}=$ nilai variabel tahun awal

$\mathrm{Xt}_{1}=$ nilai variabel tahun akhir

\section{HASIL DAN PEMBAHASAN}

\section{Perubahan Penggunaan Lahan Kota Cimahi Tahun 2007-2011}

Perubahan penggunaan lahan merupakan suatu proses bertambah atau berkurangnya luas suatu penggunaan lahan dari satu penggunaan dalam kurun waktu tertentu atau berubahnya fungsi suatu lahan dalam kurun waktu tertentu (As-Syakur, 2011). Peta penggunaan lahan tahun 2007 diperoleh dari lahan Kota Cimahi tahun 2007 yang telah diklasifikasi oleh Bappeda Kota Cimahi, sedangkan peta penggunaan lahan Kota Cimahi tahun 2011 diperoleh dari hasil interpretasi citra Quickbird tahun 2011. Penggunaan lahan di Kota Cimahi pada tahun 2007 didominasi oleh penggunaan pemukiman sebesar 1,461.5 ha $(35.9 \%)$. Proporsi penggunaan lahan pemukiman paling besar terdapat di Kelurahan Melong, hal ini disebabkan oleh jumlah penduduk di kelurahan ini paling banyak yaitu sebanyak 53,439 jiwa dibandingkan dengan kelurahan lainnya sehingga kebutuhan tempat tinggal penduduk lebih besar. Penggunaan lahan pada tahun 2011 yang mengalami penurunan luas terbesar dibandingkan tahun 2007 adalah sawah dari 585.8 ha menjadi 249 ha, diikuti oleh ladang dari 663.8 ha menjadi 444.7 ha, rumput dari 459.1 ha menjadi 95.7 ha dan perkebunan dari 223.9 ha menjadi 153.0 ha. Penurunan luas sawah terbesar terjadi di Kelurahan Cibeureum dan Melong. Hal ini sejalan dengan peningkatan luas untuk penggunaan lahan pemukiman. Komposisi masing-masing penggunaan lahan dan sebaran spasial penggunaan lahan Kota Cimahi tahun 2007 dan 2011 disajikan pada Gambar 2 dan Gambar 3.

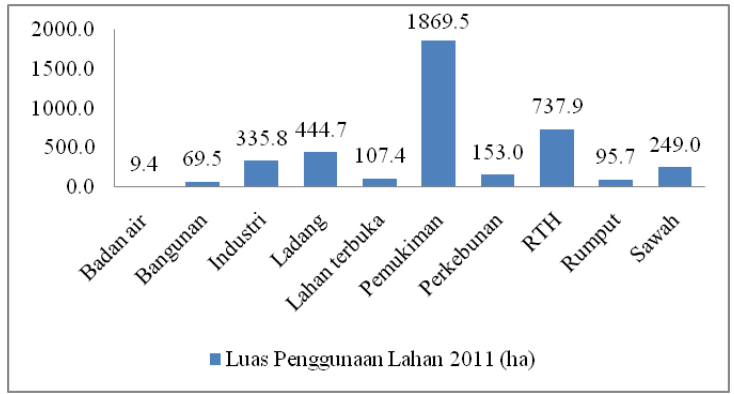

(b) Tahun 2011

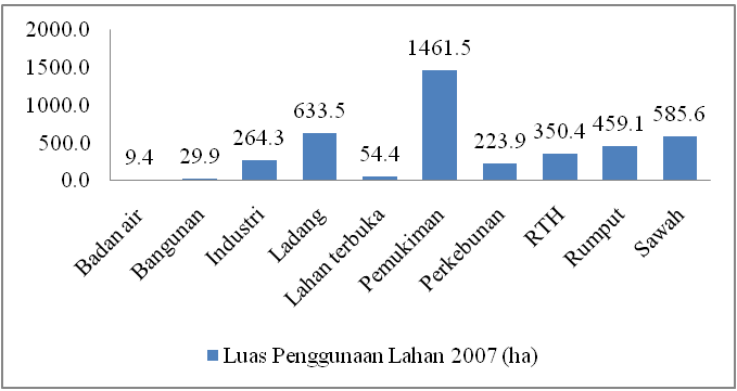

(a) Tahun 2007

Gambar 2. Komposisi masing-masing penggunaan lahan di Kota Cimahi tahun 2007 dan 2011

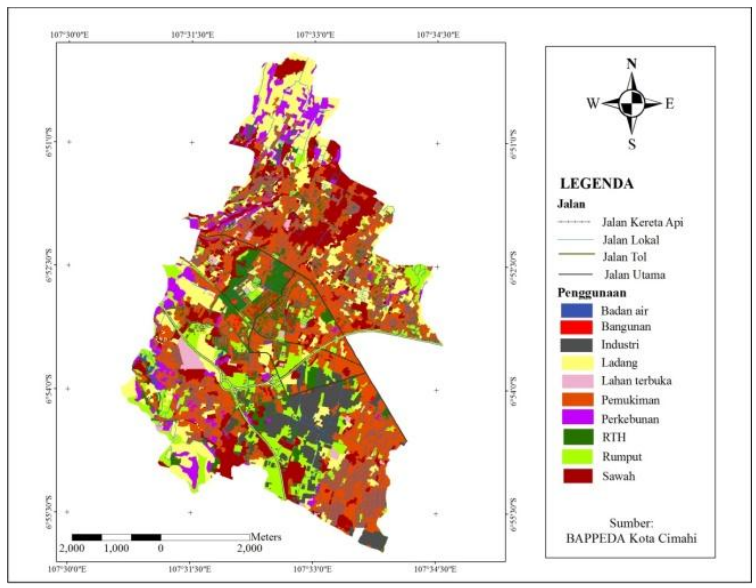

(a) Tahun 2007

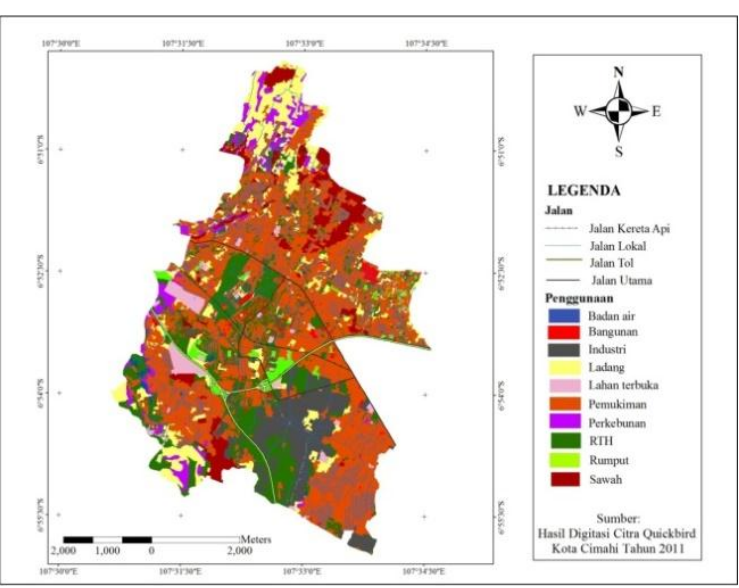

(b) Tahun 2011

Gambar 3. Sebaran spasial penggunaan lahan di Kota Cimahi tahun 2007, dan 2011 
Gambar 2 (b) menunjukkan peningkatan luas pemukiman dari $1,461.5$ ha menjadi 1,869 ha, bangunan dari 29.9 ha menjadi 69.5 ha, industri dari 264.3 ha menjadi 335.8 ha, lahan terbuka dari 54.4 ha menjadi 107.4 ha dan RTH dari 350.4 ha menjadi 737.8 ha. Selanjutnya Gambar 3 menunjukkan sebaran spasial penggunaan lahan Kota Cimahi tahun 2007 dan 2011. Pada tahun 2007, Kota Cimahi Bagian Utara didominasi oleh penggunaan lahan ladang dan sawah, sedangkan Bagian Timur dan Selatan Kota Cimahi didominasi oleh penggunaan pemukiman dan industri. Pola ini terbentuk diduga dipengaruhi oleh aksesibilitas, yaitu jaringan jalan utama kota yang berbatasan langsung dengan Kota Bandung serta jalan tol yang menjadi akses untuk keluar masuk aktivitas ke pusat pemerintahan. Jaringan jalan tersebut menjadi pemicu dibangunnya berbagai jenis fasilitas untuk menunjang aktivitas masyarakatnya. Sementara itu, di Bagian Barat Kota Cimahi didominasi oleh lahan terbuka dan RTH. Hal ini diduga karena wilayah tersebut berbatasan dengan Kabupaten Bandung yang masih didominasi oleh penggunaan lahan tidak terbangun.
Selanjutnya pada tahun 2011, penurunan luas penggunaan lahan terbesar terjadi di Bagian Selatan Kota Cimahi, yaitu di Kelurahan Cibeureum dan Melong. Peningkatan jumlah penduduk di kelurahan tersebut menyebabkan banyak penggunaan lahan terutama sawah dan ladang terkonversi menjadi lahan terbangun seperti pemukiman dan industri.

Hasil analisis perubahan penggunaan lahan tahun 2007-2011 menunjukkan bahwa penggunaan lahan yang berubah menjadi pemukiman sebesar 420.6 ha. Bentuk penggunaan lahan yang dominan dikonversi adalah lahan sawah dan ladang masing-masing sebesar 191.5 ha dan 110.4 ha. Hal ini diduga karena penggunaan lahan tersebut memiliki bentuk lahan yang relatif datar yang sangat cocok untuk lokasi pemukiman. Selain itu, peningkatan jumlah penduduk yang diiringi dengan peningkatkan kebutuhan tempat tingal menyebabkan kedua bentuk penggunaan lahan tersebut dikonversi menjadi pemukiman. Matriks perubahan penggunaan lahan Kota Cimahi tahun 2007-2011 disajikan pada Tabel 2.

Tabel 2. Matriks perubahan penggunaan lahan Kota Cimahi tahun 2007-2011 (ha)

\begin{tabular}{|c|c|c|c|c|c|c|c|c|c|c|c|}
\hline \multirow{2}{*}{$\begin{array}{c}\text { Penggunaan } \\
\text { Lahan Tahun } \\
2007\end{array}$} & \multicolumn{11}{|c|}{ Penggunaan Lahan Tahun 2011 (ha) } \\
\hline & 1) & 2) & 3) & 4) & 5) & 6) & 7) & 8) & 9) & 10) & Jumlah (ha) \\
\hline 1)Badan air & 9.4 & & & & & & & & & & 9.4 \\
\hline 2)Bangunan & & 29.8 & & & & & & & & & 29.9 \\
\hline 3)Industri & & & 264.2 & & & & & & & & 264.2 \\
\hline 4)Ladang & & 18.5 & 4.1 & 444.9 & 38.1 & 110.4 & & & 17.6 & & 633.8 \\
\hline 5)Lahan terbuka & & & & & 54.3 & & & & & & 54.3 \\
\hline 6)Pemukiman & & & & & 12.3 & 1449.2 & & & & & 1461.5 \\
\hline 7)Perkebunan & & & & & 2.7 & 48.8 & 152.9 & 14. 0 & & 5.5 & 223.9 \\
\hline 8)RTH & & & & & & & & 350.5 & & & 350.5 \\
\hline 9)Rumput & & 21.3 & 67.4 & & & 69.9 & & 222.7 & 78.0 & & 459.3 \\
\hline 10)Sawah & & & & & & 191.5 & & 150.8 & & 243.6 & 585.8 \\
\hline Jumlah & 9.4 & 69.7 & 335.8 & 444.9 & 107.4 & 1869.7 & 152.9 & 738.0 & 95.6 & 249.1 & 4072.6 \\
\hline
\end{tabular}

\section{Ketersediaan RTH Kota Cimahi Tahun 2011}

Pada tahun 2011, luas keseluruhan RTH Kota Cimahi sebesar 738 ha. Kelurahan Utama memiliki luas RTH tertinggi yaitu sebesar 158 ha atau sebesar $21.4 \%$ kemudian diikuti oleh Kelurahan Baros dengan luas RTH sebesar 86.7 ha atau $11.8 \%$ dari total keseluruhan luas RTH. Luas RTH terkecil dijumpai di Kelurahan Cimahi dengan luas 6.7 ha atau $0.9 \%$ dari total keseluruhan luas RTH. Hal ini disebabkan karena luas wilayah kelurahan tersebut relatif kecil dibandingkan dengan luas wilayah yang lainnya sehingga RTH yang ada juga relatif sedikit.

\section{a) Kecukupan RTH Kota Cimahi Berdasarkan Jumlah Penduduk}

Menurut Permen PU No. 5 tahun 2008, agar dapat melakukan aktifitas dengan nyaman setiap penduduk membutuhkan RTH seluas $20 \mathrm{~m}^{2}$. Tabel 3 menunjukkan kebutuhan RTH Kota Cimahi berdasarkan jumlah penduduk serta kecukupannya pada tahun 2011.

Tabel 3 menunjukkan luas RTH aktual Kota Cimahi pada tahun 2011 adalah sebesar 738 ha atau 17.9\% dari total seluruh wilayah sedangkan RTH yang dibutuhkan untuk memenuhi kebutuhan seluruh penduduk Kota Cimahi sebesar 1,024.58 ha. Hasil tersebut menunjukkan bahwa Kota Cimahi belum dapat memenuhi kebutuhan RTH berdasarkan jumlah penduduk. Oleh karena itu, perlu adanya penambahan RTH sebanyak 286.6 
ha untuk mencapai kecukupan RTH berdasarkan jumlah penduduk.

Kelurahan yang luas RTH nya sudah mencukupi berdasarkan jumlah penduduk yang diatur dalam Permen PU No. 5 Tahun 2008 adalah Kelurahan Baros, Cibeber, Karangmekar, Setiamanah dan Utama. 10 kelurahan lainnya memiliki luasan RTH yang belum mencukupi. Dua kelurahan yang kekurangan RTHnya paling luas adalah Kelurahan Melong sebesar 117.26 ha dan Kelurahan Cibeureum sebesar 111.95 ha. Kedua kelurahan tersebut memiliki jumlah penduduk yang paling banyak dibandingkan kelurahan lainnya sehingga peluang terjadi konversi RTH menjadi lahan terbangun cukup tinggi seperti untuk perumahan, industri, perdagangan, dan jasa.

Tabel 3. Kebutuhan RTH berdasarkan jumlah penduduk dan kecukupannya

\begin{tabular}{|c|c|c|c|c|c|c|}
\hline Kelurahan & $\begin{array}{r}\text { Jumlah } \\
\text { Penduduk } \\
\text { (jiwa) }\end{array}$ & $\begin{array}{r}\text { Luas } \\
\text { Wilayah (ha) }\end{array}$ & $\begin{array}{r}\text { Kebutuhan } \\
\text { RTH } 20 \% \\
\text { (ha) }\end{array}$ & $\begin{array}{r}\text { RTH menurut } \\
\text { Permen PU } \\
(\text { ha })^{\mathrm{a})}\end{array}$ & $\begin{array}{r}\text { Luas RTH } \\
\text { tahun } \\
2011 \text { (ha) }\end{array}$ & Selisih $(\mathrm{ha})^{\mathrm{b})}$ \\
\hline Baros & 21,053 & 243.5 & 48.7 & 42.1 & 86.7 & 44.6 \\
\hline Cibabat & 39,219 & 286.3 & 57.3 & 78.4 & 21.2 & -57.3 \\
\hline Cigugur Tengah & 53,592 & 330.5 & 66.1 & 107.2 & 58.1 & -49.1 \\
\hline Cimahi & 11,129 & 61.7 & 12.3 & 22.3 & 6.7 & -15.6 \\
\hline Cipageran & 35,466 & 574.5 & 114.9 & 70.9 & 39.5 & -31.4 \\
\hline Citeureup & 30,121 & 308.3 & 61.7 & 60.2 & 22.9 & -37.4 \\
\hline Padasuka & 40,163 & 188.7 & 37.8 & 80.3 & 14.6 & -65.7 \\
\hline Pasirkaliki & 15,860 & 217.2 & 43.4 & 31.7 & 25.0 & -6.7 \\
\hline Setiamanah & 20,419 & 114.7 & 23.0 & 40.8 & 68.9 & 28.1 \\
\hline Utama & 35,889 & 350.3 & 70.1 & 71.8 & 158.0 & 86.12 \\
\hline Jumlah & 512,290 & $4,071.8$ & 814.4 & $1,024.6$ & 738.0 & -286.6 \\
\hline
\end{tabular}

\section{b) Areal yang Berpotensi untuk Perluasan RTH}

Pembuatan peta areal yang berpotensi untuk penambahan RTH ditentukan berdasarkan 2 penggunaan lahan yang teridentifikasi tahun 2011 yaitu lahan terbuka dan rumput. Kemungkinan lahan terbuka untuk dijadikan penggunaan lain lebih besar dengan tidak mengganggu penggunaan lahan lainnya. Padang rumput dipilih karena penggunaan lahan tersebut nilai lahannya rendah dan sebagian besar kepemilikannya adalah milik publik. Kelurahan Cibeber dan Baros memiliki luas areal yang berpotensi untuk penambahan RTH paling besar dibandingkan kelurahan yang lainnya yaitu masing-masing sebesar 54.9 ha dan 27.5 ha. Kepadatan penduduk di wilayah ini cukup rendah, sementara itu luas lahan yang tersedia untuk menambah luasan areal RTH cukup besar. Kelurahan Cimahi memiliki luas areal yang berpotensi untuk penambahan RTH paling kecil karena luas wilayah kelurahannya pun kecil. Luas dan sebaran areal yang berpotensi untuk pertambahan RTH disajikan pada Gambar 4.

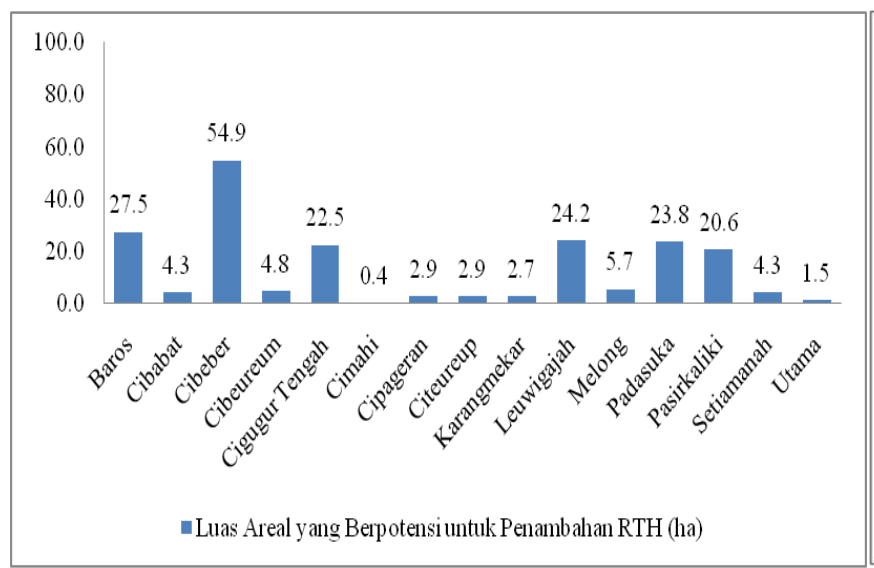

(a) Luas areal yang berpotensi untuk penambahan RTH

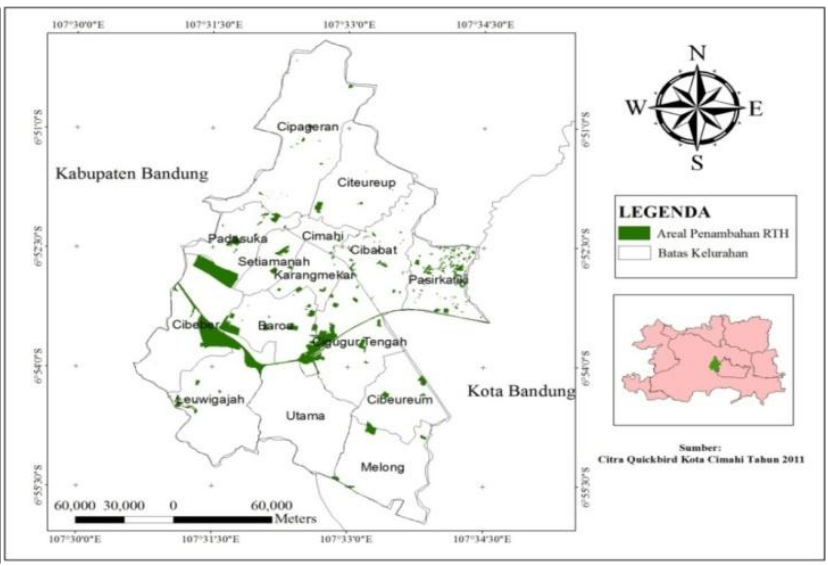

(b) Sebaran areal yang berpotensi

Gambar 4. Luas dan sebaran areal yang berpotensi untuk penambahan RTH di Kota Cimahi tahun 2011 
Hasil analisis menunjukkan areal yang berpotensi untuk penambahan RTH Kota Cimahi sebesar 203.1 ha, Luas tersebut belum bisa memenuhi Permen PU No.5 Tahun 2008 berdasarkan jumlah penduduk yang ada di Kota Cimahi yaitu sebesar 941.03 ha. Menurut proporsi Permen PU No. 5 Tahun 2008 luas RTH untuk mencukupi seluruh penduduk sebesar $1,024.58$ ha. Beberapa kelurahan yang luas RTH nya belum bisa mencukupi kebutuhan seluruh penduduk yang tinggal di wilayahnya adalah Kelurahan Cibabat, Cibeureum, Cigugur Tengah, Cimahi, Cipageran, Citeureup, Melong, dan Padasuka. Kelurahan yang sudah dapat memenuhi kebutuhan RTH menurut proporsi Permen PU No. 5 Tahun 2008 adalah Kelurahan Baros, Cibeber, Karangmekar, Leuwigajah, Pasirkaliki, Setiamanah, dan Utama.

\section{Dinamika Tingkat Perkembangan Wilayah Kota Cimahi}

\section{a) Hirarki Perkembangan Wilayah}

Hasil analisis skalogram menunjukkan bahwa hirarki wilayah dan perubahan hirarki tahun 2003-2011 seperti tertera pada Tabel 4.

Tabel 4. Hirarki wilayah berdasarkan kelurahan di Kota Cimahi tahun 2003-2011

\begin{tabular}{|c|c|c|c|c|c|}
\hline Kecamatan & Kelurahan & 2003 & 2006 & 2008 & 2011 \\
\hline Cimahi Selatan & Melong & Hirarki 1 & Hirarki 1 & Hirarki 1 & Hirarki 1 \\
\hline Cimahi Selatan & Cibeureum & Hirarki 1 & Hirarki 1 & Hirarki 1 & Hirarki 1 \\
\hline Cimahi Selatan & Utama & Hirarki 2 & Hirarki 2 & Hirarki 2 & Hirarki 2 \\
\hline Cimahi Selatan & Leuwigajah & Hirarki 2 & Hirarki 3 & Hirarki 2 & Hirarki 2 \\
\hline Cimahi Selatan & Cibeber & Hirarki 3 & Hirarki 3 & Hirarki 3 & Hirarki 3 \\
\hline Cimahi Tengah & Baros & Hirarki 2 & Hirarki 3 & Hirarki 3 & Hirarki 3 \\
\hline Cimahi Tengah & Cigugur Tengah & Hirarki 3 & Hirarki 2 & Hirarki 3 & Hirarki 3 \\
\hline Cimahi Tengah & Karangmekar & Hirarki 3 & Hirarki 3 & Hirarki 3 & Hirarki 3 \\
\hline Cimahi Tengah & Setiamanah & Hirarki 3 & Hirarki 3 & Hirarki 3 & Hirarki 3 \\
\hline Cimahi Tengah & Padasuka & Hirarki 3 & Hirarki 3 & Hirarki 3 & Hirarki 2 \\
\hline Cimahi Tengah & Cimahi & Hirarki 3 & Hirarki 3 & Hirarki 3 & Hirarki 3 \\
\hline Cimahi Utara & Pasirkaliki & Hirarki 3 & Hirarki 3 & Hirarki 3 & Hirarki 3 \\
\hline Cimahi Utara & Cibabat & Hirarki 3 & Hirarki 1 & Hirarki 2 & Hirarki 3 \\
\hline Cimahi Utara & Citeureup & Hirarki 3 & Hirarki 1 & Hirarki 2 & Hirarki 3 \\
\hline Cimahi Utara & Cipageran & Hirarki 3 & Hirarki 2 & Hirarki 2 & Hirarki 3 \\
\hline
\end{tabular}

Pada periode tahun 2003-2011 nampak bahwa Kelurahan Melong dan Cibereum konsisten berada di hirarki 1. Jumlah penduduk di kedua kelurahan tersebut paling banyak dibandingkan kelurahan yang lainnya, Selain itu, juga didukung oleh jumlah unit dan jumlah jenis fasilitas yang banyak dan beragam guna memfasilitasi kebutuhan masyarakat. Disamping itu, kelurahan tersebut dilewati oleh jalan utama kota serta berbatasan langsung dengan Kota Bandung yang merupakan Ibukota Provinsi Jawa Barat. Kelurahan Utama konsisten berada pada hirarki 2. Hal ini diduga disebabkan karena wilayah tersebut dilalui jalan tol yang menjadi salah satu akses keluar masuk aktivitas ke pusat pemerintahan sehingga menjadi daerah penunjang bagi wilayah pusatnya (hirarki 1). Kelurahan Cibeber, Karangmekar, Setiamanah, Cimahi, Pasirkaliki konsisten berada di hirarki 3. Hal ini diduga disebabkan karena jumlah dan kepadatan penduduk di daerah tersebut relatif lebih rendah dibandingkan kelurahan lainnya sehingga jumlah dan ragam fasilitas yang dibangun oleh pemerintah juga lebih sedikit. Untuk kelurahan yang lainnya yaitu Kelurahan Leuwigajah, Baros, Cigugur Tengah, Padasuka, Cibabat, Citeureup, dan Cipageran memiliki hirarki yang fluktuatif. Penurunan hirarki pada beberapa kelurahan terjadi diduga disebabkan kelurahan-kelurahan tersebut sudah jenuh dan tidak ada lagi tempat yang bisa digunakan untuk menambah fasilitas umum maupun prasarana. Akibatnya penduduk di wilayah tersebut cenderung berpindah ke wilayah pusat yang memiliki fasilitas yang lebih banyak dan beragam. Sementara itu, kenaikan hirarki diduga disebabkan oleh adanya peningkatan jumlah penduduk dan banyaknya pendatang dari wilayah lain sehingga diperlukan penambahan jumlah dan ragam fasilitas yang lebih lengkap guna menunjang kebutuhan aktifitas masyarakat. Sebagai contoh, Kelurahan Padasuka mengalami peningkatan hirarki dari hirarki 3 menjadi hirarki 2. Hal ini diduga karena adanya peningkatan jumlah fasilitas terutama toko dan restoran untuk kepentingan masyarakat. Selain itu, Kelurahan Padasuka dilalui oleh jalan arteri dan jalan kolektor yang berpengaruh terhadap perkembangan wilayah itu sendiri.

\section{b) Tingkat Perkembangan Wilayah Keterkaitannya dengan Luas RTH Kota Cimahi}

Tabel 5 menunjukkan luas RTH dan penambahan RTH Kota Cimahi berdasarkan hirarki wilayah pada tahun 2007 dan 2011. Luas RTH Kota Cimahi jika dilihat dari hirarki wilayahnya, maka hirarki wilayah 1 memiliki luas RTH paling sedikit dibandingkan dengan wilayah berhirarki 2 dan 3 . Hal ini disebabkan wilayah dengan hirarki yang lebih tinggi (hirarki 1), lahan digunakan sebagian besar untuk lahan terbangun guna memfasilitasi aktivitas wilayah pusat. Sebaliknya, di wilayah berhirarki 3 ketersediaan RTH paling tinggi. Hal ini disebabkan wilayah tersebut letaknya relatif jauh dari pusat kota dan merupakan wilayah penunjang bagi aktivitas daerah pusat, 
sehingga RTH yang tersedia cenderung lebih besar dan belum banyak terjadi konversi menjadi lahan terbangun. Namun, peluang terjadi konversi RTH menjadi penggunaan lahan lain di wilayah ini cukup besar seiring dengan peningkatan jumlah penduduk dan kebutuhan ruang untuk pembangunan permukiman dan fasilitas pelayanan.

Tabel 5. Luas dan penambahan RTH berdasarkan hirarki wilayah Kota Cimahi tahun 2007 dan 2011

\begin{tabular}{lcccc}
\hline \multirow{2}{*}{ Hirarki } & \multicolumn{2}{c}{ Luas RTH (ha) } & \multicolumn{2}{c}{$\begin{array}{c}\text { Penambahan Luas } \\
\text { RTH }\end{array}$} \\
\cline { 2 - 5 } & Tahun 2007 & Tahun 2011 & (ha) & (\%) \\
\hline Hirarki 1 & 9.5 & 29.2 & 19.8 & 5.1 \\
Hirarki 2 & 103.9 & 233.3 & 129.5 & 33.4 \\
Hirarki 3 & 237.1 & 475.3 & 238.2 & 61.5 \\
\hline Jumlah & $\mathbf{3 5 0 . 4}$ & $\mathbf{7 3 7 . 9}$ & $\mathbf{3 8 7 . 5}$ & $\mathbf{1 0 0 . 0}$ \\
\hline
\end{tabular}

Secara keseluruhan, ketersediaan RTH di Kota Cimahi mengalami peningkatan dari tahun 2007 sampai tahun 2011 yaitu sebesar 387.5 ha atau $45 \%$. Penambahan luas RTH pada tahun 2007-2011 terjadi di hirarki wilayah 1 sebesar 19.8 ha $(5.1 \%)$, hirarki wilayah 2 sebesar 129.5 ha $(33.4 \%)$ dan hirarki wilayah 3 sebesar 238.2 ha (61.5\%). Kelurahan Cibeureum memiliki luas RTH terbesar dibandingkan dengan Kelurahan Melong yang berada di hirarki 1 yaitu sebesar 7.1 ha pada tahun 2007 dan 14.7 ha pada tahun 2011. Kelurahan Utama konsisten berada di hirarki 2 dengan luas RTH terbesar dibandingkan kelurahan lainnya yang berada di hirarki 2, yaitu 42 ha pada tahun 2007 dan 157.9 ha pada tahun 2011. Kelurahan Karangmekar berhirarki 3 memiliki luas RTH terbesar pada tahun 2007 dibandingkan dengan kelurahan lain berhirarki 3 yaitu sebesar 58 ha, sedangkan pada tahun 2011 Kelurahan Baros memiliki RTH terbesar dibandingkan dengan kelurahan berhirarki 3 lainnya yaitu sebesar 86.7 ha.

\section{Faktor-Faktor yang Mempengaruhi Ketersediaan Ruang Terbuka Hijau di Kota Cimahi}

Ketersediaan RTH di Kota Cimahi dipengaruhi oleh beberapa faktor. Untuk mengetahui faktor-faktor yang mempengaruhi ketersediaan RTH di Kota Cimahi digunakan analisis regresi berganda dengan metode regresi bertatar. Hasil analisis menunjukkan bahwa persamaan regresi yang dihasilkan memiliki nilai R-square $\left(\mathrm{R}^{2}\right)$ sebesar 0.86. Hal ini menunjukkan bahwa data yang ada relatif mampu untuk menjelaskan/mengidentifikasi variabel penting penentu ketersediaan RTH karena $\mathrm{R}^{2}$ yang cukup besar mendekati 1 . Tabel 6 , menunjukkan bahwa variabel penduga yang berpengaruh sangat nyata secara statistik (p-level $<0.05)$ adalah alokasi lahan terbangun dalam RTRW dan kepadatan penduduk, sedangkan variabel lainnya yaitu jumlah jenis fasilitas, pertumbuhan penduduk, dan lahan terbangun tahun 2011 kurang berpengaruh terhadap ketersediaan RTH Kota Cimahi tahun 2011.

Tabel 6. Hasil analisis regresi

\begin{tabular}{lrrrrrr}
\hline Variabel & Beta & \multicolumn{1}{c}{ Std.Err. } & \multicolumn{1}{c}{ B } & \multicolumn{1}{c}{ Std.Err. } & \multicolumn{1}{c}{$\mathrm{t}(9)$} & $\mathrm{p}$-level \\
\hline Intercept & & & 119.72 & 44.38 & 2.70 & 0.02 \\
Alokasi Lahan Terbangun & 0.78 & 0.14 & 0.39 & 0.07 & 5.68 & 0.00 \\
dalam RTRW & -0.46 & 0.16 & -0.00 & 0.00 & -3.00 & 0.02 \\
Kepadatan Penduduk & -0.19 & 0.13 & -2.47 & 1.76 & -1.42 & 0.19 \\
Jumlah Jenis Fasilitas & 0.22 & 0.17 & 88.40 & 66.94 & 1.32 & 0.22 \\
Pertumbuhan Penduduk & -0.14 & 0.14 & -0.08 & 0.08 & -1.00 & 0.34 \\
Lahan terbangun 2011 & 0.86 & & & & & \\
\hline $\mathrm{R}^{2}=$ & 19.00 & & & & & \\
$\mathrm{SE}=$ & & & & & &
\end{tabular}

\section{SIMPULAN}

1. Pada kurun waktu tahun 2007-2011 terjadi perubahan penggunaan lahan di Kota Cimahi yang ditunjukkan oleh peningkatan luas penggunaan lahan pemukiman, $\mathrm{RTH}$, industri, bangunan, dan lahan terbuka dan penurunan luas penggunaan lahan sawah, ladang, rumput dan perkebunan serta luas badan air tetap.

2. Luas RTH Kota Cimahi saat ini sebesar 738 ha atau $17.9 \%$ dari luas seluruh wilayah sehingga belum bisa mencukupi kebutuhan RTH ditinjau dari luas wilayah menurut UU No. 26 Tahun 2007 pasal 29 dan jumlah penduduk Kota Cimahi menurut Permen PU No. 05/PRT/M/2008.
3. Faktor-faktor yang berpengaruh nyata terhadap ketersediaan RTH di Kota Cimahi adalah alokasi lahan terbangun dalam RTRW dan kepadatan penduduk, sedangkan jumlah jenis fasilitas, pertumbuhan penduduk dan lahan terbangun 2011 tidak berpengaruh nyata terhadap ketersediaan RTH di Kota Cimahi. Alokasi lahan terbangun dalam RTRW dan pertumbuhan penduduk berpengaruh positif dalam meningkatkan ketersediaan RTH, sedangkan kepadatan penduduk, jumlah jenis fasilitas, dan lahan terbangun tahun 2011 berpengaruh negatif atau cenderung menurunkan ketersediaan RTH di Kota Cimahi.

4. Dinamika tingkat perkembangan wilayah di Kota Cimahi menunjukkan ada kelurahan-kelurahan yang konsisten berada di hirarki 1,2 dan 3, dan ada pula 
yang fluktuatif berupa penurunan dan peningkatan hirarki. Kelurahan Melong dan Cibeureum konsisten berada di hirarki 1, Kelurahan Utama konsisten berada di hirarki 2, sedangkan Kelurahan Cibeber, Karangmekar, Setiamanah, Cimahi dan Pasirkaliki konsisten berada di hirarki 3. Tujuh kelurahan lainnya yaitu Kelurahan Leuwigajah, Baros, Cigugur Tengah, Padasuka, Cibabat, Citeureup, dan Cipageran mengalami hirarki yang sifatnya fluktuatif antar waktu.

\section{DAFTAR PUSTAKA}

As-syakur, A.R. 2011. Perubahan penggunaan lahan di Provinsi Bali. Ecothropic, 6: 2011.

Badan Lingkungan Hidup Kota Cimahi. 2011. Laporan Pendahuluan Pekerjaan Pengelolaan Ruang Terbuka Hijau Kota Cimahi. Cimahi.

Direktorat Jenderal Penataan Ruang. 2007. UndangUndang Republik Indonesia Nomor 26 Tahun 2007 tentang Penataan Ruang. Direktorat Jenderal Penataan Ruang. Departemen Pekerjaan Umum. Jakarta.
Dwiyanto, A. 2009. Kuantitas dan kualitas ruang terbuka hijau di permukiman perkotaan. Teknik, 30: 88-92.

Menteri Pekerjaan Umum Republik Indonesia. 2008. Peraturan Menteri Pekerjaan Umum Nomor 05/PRT/M/2008 tentang Pedoman Penyediaan dan Pemanfaatan Ruang Terbuka Hijau di Kawasan Perkotaan.

Pemerintah Kota Cimahi. 2012. Sejarah Kota Cimahi. Cimahi.

Rahmi, D.H. 2002. Penyediaan ruang terbuka hijau di lingkungan perumahan di Yogyakarta. Jurnal Manusia dan Lingkungan, IX: 101-114.

Samsudi. 2010. Ruang terbuka hijau kebutuhan tata ruang perkotaan Kota Surakarta. Journal of Rural and Development, 1: 11-19.

Sitorus, S.R.P., W. Aurelia, dan D.R. Panuju. 2011. Analisis perubahan luas ruang terbuka hijau dan faktor-faktor yang mempengaruhinya di Jakarta Selatan. Jurnal Landskap Indonesia, 3: 15-20. 